\title{
E-banking and its growth in India - A synoptic view
}

\author{
Suhas. ${ }^{1, *}$, H N. Ramesh ${ }^{2}$ \\ ${ }^{1}$ Research Scholar, ${ }^{2}$ Professor, Institute of Management Studies, Kuvempu University, Shankaraghatta, Shimoga, India
}

*Corresponding Author: Suhas. D

Email: dvgsuhas@gmail.com

\begin{abstract}
Now a day's contribution of Electronic banking towards economic development plays a crucial role in developing countries like India. Banks are no longer restricted to traditional banking rather it is shifted to the virtual banking system. Customers are experiences more feasible in banking operations because of Information technology. The banks are adopting IT-enabled tools and techniques for banking operations which improve in offering quality service to the customers. In traditional banking customers has to visit bank branches to avail banking services. Now with the ATMs, Internet banking, Mobile banking and Information Technology-enabled services are replacing the traditional method of service. In the recent days banks are concentrating on value-based service through E-banking. The present study throws a light on the growth of Electronic banking and its product which are used in the banking sector.
\end{abstract}

Keywords: Electronic banking, Economic development, ATMs, Informational technology.

\section{Introduction}

A Bank is a Financial Institution which is among the main contributors to the financial system in India. Banking offers various facilities to the customer for baking operations. Since the nationalisation of banks in 1969, the public sector banks, possessed by the government, have acquired a place of nobility, with incredible growth. Now India is becoming an emerging economic giant because of information technology. Banking in India has been through a long journey. It has seen a number of changes due to technology and innovation. The globalization exhaustively transformed the face of Indian banking industry from past few years. Banks have customarily been in the front position of exploiting technology to ameliorate their products/services and working competence. Over a long period of time banks have been utilizing electronic and telecommunication modes for distributing a wide range of value integrated product/services. The influx of cards, the introduction of clearing services like ECS, the concept of e-banking and mobile banking are the numerous innovations which took place in the banking segment. Now a days all the banks have started with the concept of multi-channel, like debit cards, credit cards, smart cards, ATMs, internet banking, mobile banking/telephone banking, electronic fund transfer, etc. the role of banks has changed from financial intermediate to service supplier of numerous monitory service under a roof. Today, modern banking not only looks for new ways to attract but also to retain the customers and gain a competitive advantage over their competitors.

\section{E-Banking - A Conceptual View}

Electronic banking (e-banking) is defined as the automated delivery of new and traditional banking products and services directly to customers through electronic, interactive communication channels (Daniel, 1999; Sathye, 1999).

Efficient implementation of supporting technology for allowing a variety of electronic banking has bought a new revolution for the delivery of banking facilities. With the increasing popularity and benefits of e-banking, a lot of banks have recognised the importance, competition and challenges carried out with this new technology and are adapting to this new-age banking.

\section{Literature Review}

Kamakodi et al. (2008) expressed that an extensive gap exists in human service in Indian banking while IT-based facilities are beyond the expectations. Qureshi T M, Zafar M K and Khan M B (2008) evaluated the customer acceptance of online banking study concludes that majority of customers are accepting online banking culture because of favourable factors and usefulness, security and privacy. Uppal R K (2010) expressed in his research, ATMs is the most effective while mobile banking does not hold a strong position in public sector banks, Mobile banking customers are also the highest in E-Banks which have a positive impact on net profit and business per employee. Mishra (2011) delivered a useful advice to safeguard the safety of internet-based transactions (IBT). The customer of the banks should not reply to any SMS, calls or Emails, requesting for password and not to connect on any link for banks website. E-Banking has arisen from such an advanced improvement. Zamdi et al (2013), studying 56 countries over 2008-12, calculate that USD 983 billion were added to their cumulative real GDP because of increased card usage. Among the emerging economies, India at a lower level of $0.047 \%$. Dhananjay B and Suresh Chandra B (2015) expressed that retail electronic payment system has progressed in the recent years. The creation of NCPI set the stage for the development of Electronic payments. In this ratio of electronic clearing grew from one percent to three percent. Mukhopadhyay (2016) in their study of benefits from cashless society found that as more payments are directly credited to the account, cashless payments increase significantly. Dr. Karunagupta, Mr. Ravindraarya, (2017) focused on emerging trends in the banking sector in India, he focused on the banking sector with reference to digitalization. The digitalization of banking system leads to a strong foundation in of economy and to ready to become cashless economy to transform the Indian banking industry. 


\section{Research Methodology}

The present study is based on secondary data. It is analytical and descriptive in nature. The statistical tools used for this study is Simple Growth Rate, Average, Trend Lines or Linear lines and Compound Annual Growth Rate are obtained to evaluate the data. Data has been collected for the period of April 2013 to April 2018 from Reports on Trends and progress of banking in India and Statistical Table relating to banks in India from Reserve bank of India website. In this study, the simple growth rate is indicated by GR and below given formula is used for the calculation of GR.

$$
\mathrm{GR}=(\mathrm{Vt}-\mathrm{Vt}-1) / \mathrm{Vt}-1 \times 100
$$

Where: Vt indicates the value of a given parameter in the current year and

$\mathrm{Vt}-1$ indicates the value of a given parameter in the previous year.

Simple tabular analysis and relevant graphs are used for analysis purpose wherever found relevant for a particular study.

CAGR is a comparatively simple metric which measures the average rate of an investment's growth over a variable period of time. CAGR is used to calculate the overall growth rate of e-banking services provided by the Indian banking industry over a specific period of time i.e. from 2013 to 2018. The formula to calculate CAGR is given below:

$\mathrm{CAGR}=(\text { Ending value } / \text { Beginning value })^{\wedge}(1 / 1-$ t years $)-1$

\section{The Growth of E-banking in India}

Till 1990s banks are adopted traditional method of banking over branch banking. After financial reforms, the banking business also viewed the innovative movement of banking services. The Indian banking sector has accepted computerisation since 1993, more out of sheer compulsion and necessity to cope up increasing overload and incompatibility of the manual system to sustain further growth. In 1993, the employees' association of the Indian banks (IBA) contracted an agreement with the bank management about the introduction of computerised application in banks. This agreement was the major breakthrough in the introduction of computerised applications and the development of communication networks in banks. The first initiative in the area of bank computerisation, however, stemmed out of the landmark reports of the two committees headed by former RBI governor, Dr. C Rangarajan. Both the reports had strongly recommended computerisation of banking operations at various levels and suggested appropriate architecture.

In the year 1994 Reserve bank of India created a committee under the head of W S Saraf, the committee strongly recommended the use of Electronic fund transfer (EFT), the introduction of electronic clearing services and extension of Magnetic Ink Character Recognition (MICR) beyond metropolitan cities and branches. In 1996 Industrial Credit and Investment Corporation of India was the first to use Electronic banking in India by introducing online banking services in branches. Its initiatives were followed by HDFC Bank, IndusInd Bank and Citibank, who started provided online banking facilities in 1999. Reserve bank of
India and government of India have been taken various initiatives for the expansion and smooth functioning of Electronic banking in India. The government of India passed the IT Act, 2000 which delivers a legal acknowledgement to e-transactions and E-commerce.

The significant technical growths viewed in the new age payment structures in India are:

1. In 1980 to 1990's - Arrival of debit card and credit card

2. From 1984 to 1988 - Banks started using computers, MICR cheques were introduced.

3. In $1987-$ HSBC is the first bank to introduce the ATM concept in India

4. In 1990 - ECS payment was introduced in India by the RBI

5. In 1991 - India joined Society for Worldwide Interbank Financial Telecommunication.

6. In 1997 - Shared payment network system has been set up

7. In 1999 - A pilot project for Smart cards conducted jointly by Reserve bank of India, IIT (Mumbai) and IDRBT, Hyderabad

8. In 2000 - Information Technology act was passed,

9. In 2002 - mobile banking was started in India by way of SMS banking

10. In 2003 - Introductions of Special Electronic fund transfer

11. In 2004 - Introduction of Real-time gross settlement

12. In 2005 - overall 11 Percent of branches of Public sector banks have been brought under Core banking solutions and the introduction of national electronic funds transfer.

13. In 2007 - the payment and settlement system act, 2007 was passed

14. In 2008 - Introduction of Cheque truncation system and operative guidelines on mobile banking transactions were issued.

15. In 2009 - Free cash withdrawal from ATMs.

16. In 2010 - Introduction of Immediate payment service

17. In 2016- Bharat bill payment system \& Unified Payments Interface is stated in banks across the country started to upload their interface in August 2016.

18. In 2016 - Bharat Interface for Money (BHIM) is a mobile app developed by National Payments Corporation of India (NPCI), based on the Unified Payment Interface (UPI).

\section{Traditional Banking V/s Electronic Banking}

In traditional banking, personally the customers have to visit the branches to perform the banking transactions, whereas in electronic banking it enables the customer to make banking transactions with the help of computer or laptop by sitting at their house or workplace. The customer has to spend money to visit branches of the bank whereas in Electronic banking it helps the customer to perform banking activities easier, faster and convenient and also makes available round the clock irrespective of the customer's location. In traditional banking the employees can give limited service, in electronic banking, the customer does not have to stand in queues to out certain bank transactions. 


\section{Electronic Banking Products in India}

In the recent past, a large number of banking services shifted from Traditional banking to E-Banking. The present study focuses on the important forms of E-banking such as ATM, Debit cards, Credit cards, RTGS, Mobile Banking.

\section{Automated Teller Machine}

An ATM is a computerised machine that provides the customer to make a financial transaction without the help of a bank employee. For using an ATMs, the customer has to obtain an ATM card or debit card from his bank. Using an ATMs a customer can avail various service like withdrawal of cash, depositing money, check the balance inquiries etc. The system is recognised as "Any Time Money" or "Anywhere Money" as it permits the customers to withdraw money from the bank from any of its ATMs without any constraint of time, ATMs is also beneficial for the customer who regularly visits foreign countries. They can withdraw money in foreign nations. The currency will be converted at the financial institution's exchange rate. Nowadays ATMs are considered one of the easiest modes of withdrawing money.

The below-given table and chart show the increase in ATM deployment by the banks in India from the period 2013 to 2018. It is clear from the table and chart that the number of ATM deployed by the banks are increased from 1.16 lakhs to 2.07 lakhs between the periods 2013 to 2018 and it is showing a slow growth rate in the year 2018 compare to the previous year 2017 and overall compound annual growth rate showing 12.31 percent.

Table and Chart: 1 ATMs deployed by the banks in India

\begin{tabular}{|l|c|c|}
\hline Year & Number of ATMs & Growth rate \\
\hline April 2013 & 116378 & - \\
\hline April 2014 & 162543 & 39.67 \\
\hline April 2015 & 182480 & 12.27 \\
\hline April 2016 & 199954 & 9.58 \\
\hline April 2017 & 207813 & 3.93 \\
\hline April 2018 & 207920 & 0.05 \\
\hline Total & 1077088 & \multirow{2}{*}{} \\
\cline { 1 - 2 } Average & 179514.67 & \\
\cline { 1 - 2 } CAGR & $12.31 \%$ & \\
\hline
\end{tabular}

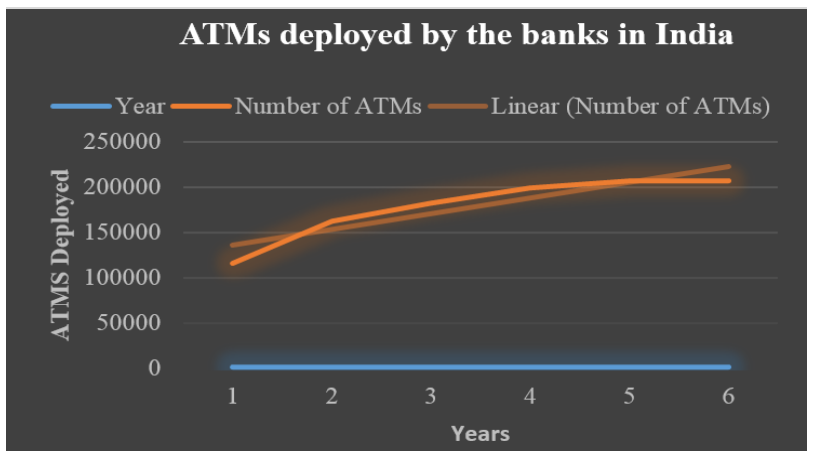

Source: Authors' own calculation, basic data collected from the Reserve Bank of India

\section{Debit Cards}

A debit card is a plastic card, which delivers an alternative payment system to cash when we make purchases. Customer need not carry paper cash, instead of using paper cash, they can use their cards to cash withdrawal and make purchases. In India, the majority of the banks provide debit cards whenever a customer opens a saving bank account. As and when cash is a required customer can withdraw money with the help of Debit card. It also enables customers to use ATM machines. The customer can withdraw the money if he has sufficient balance in his account with the bank. Although many debit cards are of the Rupay card, Visa or Master card kind, there are many other forms of a debit card, each recognised only within a particular country. Customer needs to be most careful when they are making transactions.

The below table and chart -2 shows the number of debit cards issued outstanding (after adjusting the number of cards withdrawn/cancelled) from April 2013 to April 2018. As is clear there has been an increased from $33.68 \mathrm{Cr}$. to $90.63 \mathrm{Cr}$. in the issue of debit cards by the banks and the increase in issuing of debit cards in the period 2013 to 2018 has been more than double. Average of issuing debit cards are 60.99 $\mathrm{Cr}$. Growth rate of issuing debit cards was at the top in the year 2015 and it is showing a constant growth rate in last three years and overall compound annual growth rate indicating 22 percent. Chart-2 represents the growth of Debit cards issues outstanding with the trend/linear line.

Table and Chart 2: Showing total number of debit cards issued outstanding

\begin{tabular}{|l|c|c|}
\hline Year & Debit Cards & Growth rate \\
\hline Apr-13 & 336866879 & - \\
\hline Apr-14 & 399652017 & 18.64 \\
\hline Apr-15 & 564707913 & 41.30 \\
\hline Apr-16 & 671187187 & 18.86 \\
\hline Apr-17 & 780795417 & 16.33 \\
\hline Apr-18 & 906356781 & 16.08 \\
\hline Total & 3659566194 & \\
\hline Average & 609927699 & \\
\hline CAGR & $22 \%$ & \\
\hline
\end{tabular}

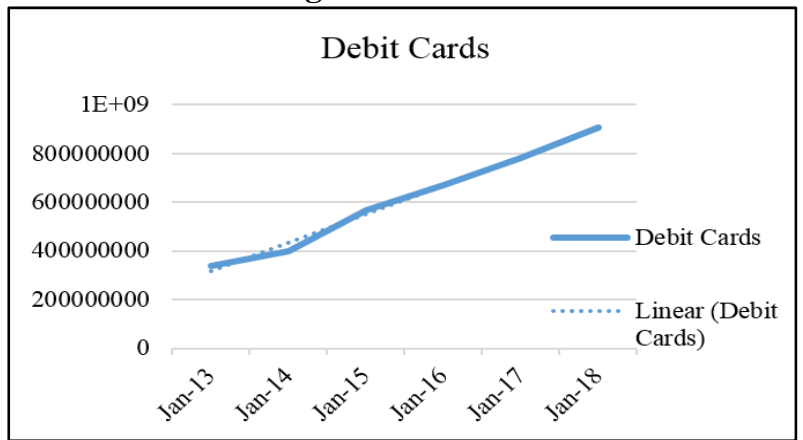

Source: Authors' own calculation, basic data collected from the Reserve Bank of India 


\section{Credit Cards}

A credit card is also known as plastic money which permits its customer to buy goods and services on credit bases. The credit cards are given by the banks, and when customers sweep the card for their purchases a line of credit is granted by him, as he can make purchases on credit bases which are to be repaid later to the bank. A credit card transaction is often more secure than other forms of payment such as cash payments or cheque payments. Customers have a fear to use credit cards because it leads to more spending than required. It also involved a high risk of fraud if in case the card gets stolen or if the card's information is shared unknowingly.

The below-given table shows the number of credit cards issued outstanding (After adjusting the number of cards withdrawn/cancelled) from April 2013 to April 2018. It is clear from the table that the number of credit cards issued has been an increase from $1.95 \mathrm{Cr}$. To $3.77 \mathrm{Cr}$. between the period 2013 and 2018. We can identify the negative growth rate in the year 2014, and continuously increasing in subsequent years. The overall Compounded annual growth rate shows 14 percent. Chart-3 represents the growth of credit cards issues outstanding with the trend/linear line.

Table and Chart- 3: Showing total number of credit cards issued outstanding

\begin{tabular}{|c|c|c|}
\hline Year & Credit Cards & Growth rate \\
\hline Apr-13 & 19553677 & - \\
\hline Apr-14 & 19226475 & -1.67 \\
\hline Apr-15 & 21288891 & 10.73 \\
\hline Apr-16 & 24860730 & 16.78 \\
\hline Apr-17 & 30374102 & 22.18 \\
\hline Apr-18 & 37782876 & 24.39 \\
\hline Total & 153086751 & \\
\hline Average & 25514458.5 & \\
\hline CAGR & $14 \%$ & \\
\hline
\end{tabular}

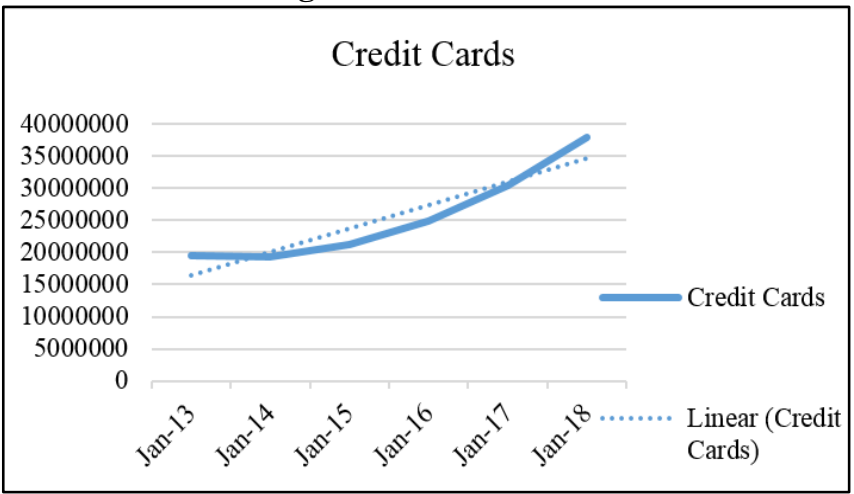

Source: Authors' own calculation, basic data collected from the Reserve Bank of India

\section{National Electronic Fund Transfer}

National electronic fund transfer is a nation-wide payment system enabling one to one fund's transfer. Under this system individuals and corporates can electronically transfer funds from any bank branch to any individual, corporate having an account with any other bank branch in the country participating in the scheme. For being a part of the NEFT funds transfer network, a bank branch has to be National electronic fund transfer enabled. Any individuals, firms who holds saving bank accounts with a bank branch can receive or send funds through the NEFT scheme hence it is necessary for the customers to have an account with NEFT enabled bank branch. There is no maximum limit on the number of funds that could be transferred using NEFT. From
July 10, 2017 onwards the settlements of fund transfer requests in the NEFT system is done on a half-hourly basis.

The below-given table shows the NEFT transactions in forms of Volume (Million) and Value (Billion) made by banks from the period of 2012-13 to 2017-18. From the below table we can observe that NEFT transactions increased in volume and value of transactions from 394.13 million to 1946.36 million for period 2012-13 to 2017-18. And it shows the positive growth rate in NEFT transactions in form of volume and value. The overall Compounded annual growth rate of volume and value shows 38 percent and 43 percent respectively. Chart 4 represents the growth of NEFT transactions in form of volume and value with the trend/linear line.

Table 4: NEFT transactions in form of volume and value

\begin{tabular}{|l|c|c|c|c|}
\hline Year & $\begin{array}{c}\text { NEFT Volume } \\
\text { (Million) }\end{array}$ & $\begin{array}{c}\text { Growth } \\
\text { rate }\end{array}$ & $\begin{array}{c}\text { NEFT Value } \\
\text { (Billion) }\end{array}$ & $\begin{array}{c}\text { Growth } \\
\text { rate }\end{array}$ \\
\hline Apr-13 & 394.13 & - & 29022.42 & - \\
\hline Apr-14 & 661.01 & 67.71 & 43785.52 & 50.87 \\
\hline Apr-15 & 927.55 & 40.32 & 59803.83 & 36.58 \\
\hline Apr-16 & 1252.88 & 35.07 & 83273.11 & 39.24 \\
\hline Apr-17 & 1622.1 & 29.47 & 120039.68 & 44.15 \\
\hline Apr-18 & 1946.36 & 19.99 & 172228.52 & 43.48 \\
\hline Total & 6804.03 & & 508153.08 & \\
\hline Average & 1134 & & 84692 & \\
\hline CAGR & $38 \%$ & & $43 \%$ & \\
\hline
\end{tabular}


Chart 4: NEFT transactions in form of volume and value

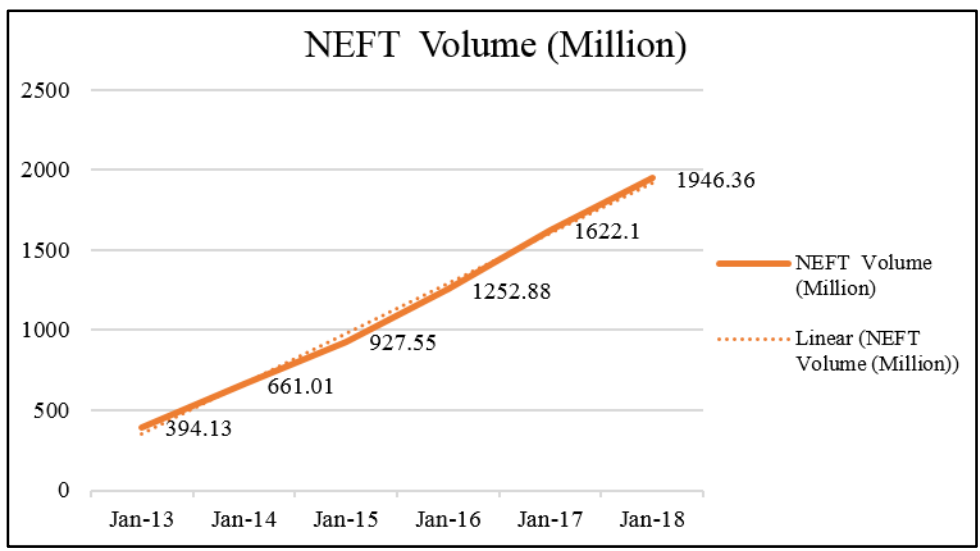

Source: Authors' own calculation, basic data collected from the Reserve Bank of India

\section{Real Time Gross Settlement}

It is defined as the continuous settlement of funds transfer separately on an order by order basis. Real-time means processing of orders at the time they are received rather than at some later time, Gross settlement means the settlement of funds transfer instructions take place individually (on an instruction by instruction basis). Considering that the fund's payment takes place in the books of the RBI, the payments are ultimate and irrevocable. RTGS is mainly meant for large value transactions. The lowest amount to be settled through RTGS is Rs. Two lakhs and there is no upper limit for RTGS transactions. The banks have to transfer the funds from one account to another on a realtime basis, which the customer can receive the amount within thirty minutes from receiving the fund's transfer message. The RTGS service for customer's transactions is available to the bank from 9:00 AM to 16:30 PM on working days.
Charges levied by banks for offering fund transfer through RTGS system, there are no charges for Inward transactions made through RTGS, for outward transactions Rs 30 is charged for the transactions of Rs 2 lakh to 5 lakh, and Rs 55 is charged for the transactions above 5 lakhs.

The below-given table shows the RTGS transactions in forms of Volume (Million) and Value (Billion) made by banks from the period of 2012-13 to 2017-18. From the below table we can observe that RTGS transactions increased over a period of time in the forms of volume as well as value. And it shows the variability in growth rate with respect to the volume and value of RTGS transactions. The overall Compounded annual growth rate of volume and value of RTGS transactions shows 13 percent and 7 percent respectively. Chart-5 represents the growth of RTGS transactions in form of volume and value with the trend/linear line.

Table 5: RTGS Transactions in form of volume and value

\begin{tabular}{|c|c|c|c|c|}
\hline Year & $\begin{array}{c}\text { RTGS Volume } \\
\text { (Million) }\end{array}$ & $\begin{array}{c}\text { Growth } \\
\text { rate }\end{array}$ & $\begin{array}{c}\text { RTGS Value } \\
\text { (Billion) }\end{array}$ & $\begin{array}{c}\text { Growth } \\
\text { rate }\end{array}$ \\
\hline Apr-13 & 68.52 & - & 1026350.05 & - \\
\hline Apr-14 & 81.11 & 18.37 & 904968.04 & -11.83 \\
\hline Apr-15 & 92.78 & 14.39 & 929332.89 & 2.69 \\
\hline Apr-16 & 98.34 & 5.99 & 1035551.64 & 11.43 \\
\hline Apr-17 & 107.86 & 9.68 & 1253652.08 & 21.06 \\
\hline Apr-18 & 124.46 & 15.39 & 1467431.99 & 17.05 \\
\hline Total & 573.07 & & 6617286.69 & \\
\hline Average & 95.51 & & 1102881.12 & \\
\hline CAGR & $13 \%$ & & $7 \%$ & \\
\hline
\end{tabular}


Chart 5: RTGS transactions in form of volume and value

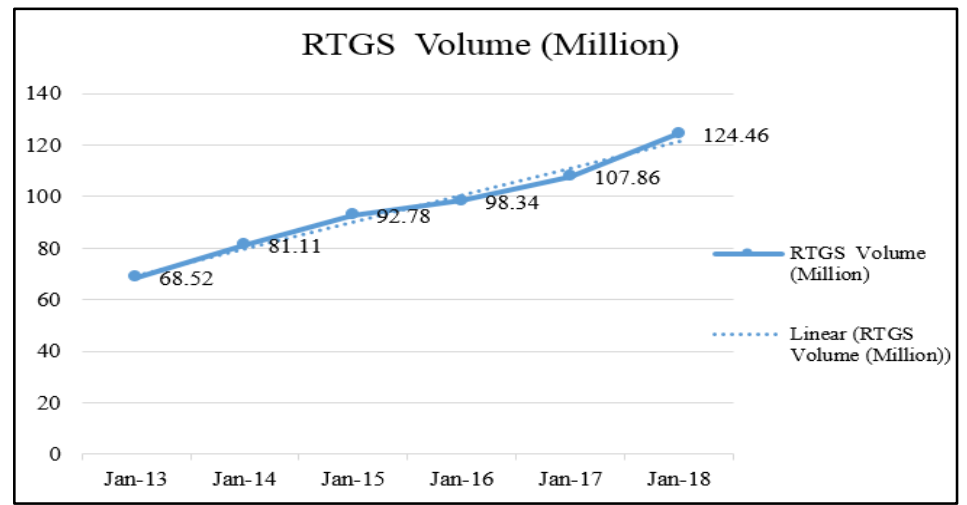

Source: authors' own calculation, basic data collected from the reserve bank of India

\section{Mobile Banking}

It is the act of performing banking transactions on a mobile device like cell phones, tablet etc. mobile phones as a medium for covering banking services, and have reached greater significance because of their pervasive nature. Banks are allowed to offer mobile banking services through SMS, USSD or mobile banking application after obtaining necessary permission from the department of payment and settlement systems. Mobile banking services are to be made available to bank customers irrespective of the mobile network. Banks which are licensed and have a physical presence in India, only banks who have implemented Core banking solutions are permitted to offer mobile banking service for the customer, To enable mobile banking service the customer should fulfil Know your customer norms.

The below-given table shows the Mobile banking transactions in forms of Volume (Million) and Value (Billion) made by banks from the period of 2012-13 to 201718. From the below table we can observe that Mobile banking transactions increased significantly over a period of time. And it shows the high in growth rate in the year 2016 and 2017 in form of volume, 2014 and 2015 in form of the value of mobile banking transactions. The overall Compounded annual growth rate of volume and value of mobile banking transactions shows more than 100 percent i.e., 104 percent and 201 percent respectively. Chart- 6 represents the growth of mobile banking transactions in form of volume and value with the trend/linear line.

Table 6: Mobile banking transactions in form of volume and value

\begin{tabular}{|l|c|c|c|c|}
\hline Year & Mobile Volume (Million) & Growth rate & Mobile Value (Billion) & Growth rate \\
\hline Apr-13 & 53.3 & - & 59.9 & - \\
\hline Apr-14 & 94.71 & 77.69 & 224.18 & 274.26 \\
\hline Apr-15 & 171.92 & 81.52 & 1035.3 & 361.82 \\
\hline Apr-16 & 389.49 & 126.55 & 4040.91 & 290.31 \\
\hline Apr-17 & 976.85 & 150.80 & 13104.76 & 224.30 \\
\hline Apr-18 & 1872.26 & 91.66 & 14738.54 & 12.47 \\
\hline Total & 3558.53 & & 33203.59 & \\
\hline Average & 593.09 & & 5533.93 & \\
\hline CAGR & $104 \%$ & & $201 \%$ & \\
\hline
\end{tabular}

Chart 6: Mobile banking transactions in form of volume and value

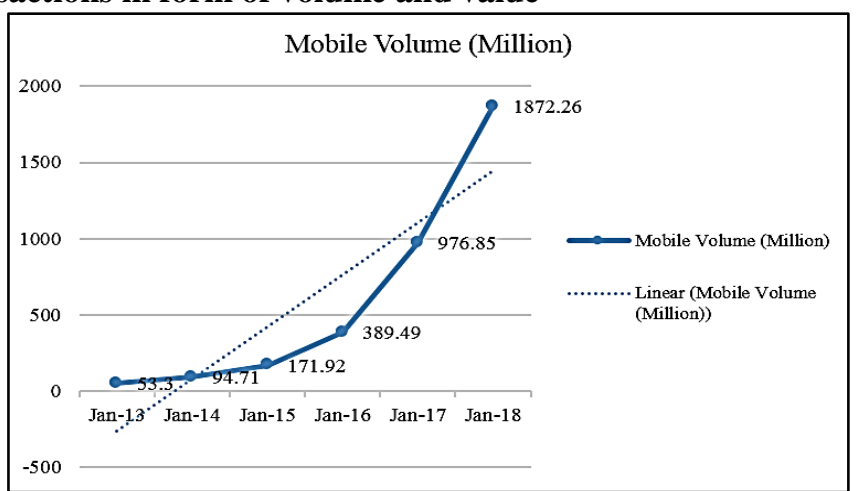

Source: Authors' own calculation, basic data collected from the Reserve Bank of India 


\section{Factors Causing E-banking Success}

Compared to western countries, E-banking practices in India is significantly low. In recent years banks have attempted to create information infrastructure to enhance the E-banking operation. Some of the factors which are responsible for E-banking implementation are:

1. Channel convenience is a factor which plays a crucial role in adopting internet banking, which helps the customers to access $24 \times 7$ and time-saving.

2. E-banking provides enhanced services to a customer like banks regularly invests new online products and interactive customer care mode is available to instantly solve queries.

3. Cost and promotion is the factor which helps the customer to do the transaction online because it is cheaper than branch banking and extensive promotion and advertisements about e-banking help in created awareness

4. Prior internet knowledge and Information on internet banking helps the customer to do banking activates quickly and safely.

5. Nowadays banks assuring their customer about Security and privacy which gives confidence among customer, where banks safely maintain the information of the customer without any kind of leakage.

\section{Challenges in Adopting Electronic Banking}

Now a day's Electronic banking is a norm rather than an exception for the banks. But in spite of it offers numerous assistance for the customer to make banking easy and convenient but there are many challenges which customers are facing in the adoption of Electronic banking. Some of the challenges are as stated below:

1. Customers refuse to adopt Electronic banking service because of Security threat Electronic banking frauds like spyware, Phishing, internet theft Spamming etc. are still very much widespread.

2. Customers are having a threat of loss of private information due to technical faults.

3. Insufficient knowledge of using electronic banking and lack of preparedness by customers and banks in technological adoption.

4. Insufficient infrastructure for the setting up of Electronic delivery networks

5. The bank's management, supervisor and governing authorities are facing several challenges in adoption of E-banking.

6. The risk of revealing the financial information of the customers with others hence Customers are having a fear of privacy issue.

7. Communication through an internet might not be the best base for bank and customer relations as belief might partially be lost.

\section{Conclusion}

Virtual banking is given a momentum for banks to provide quality service through Information technology. We are moving towards a cashless society with the help of digitalization and it is going to be strengthening the bank's performance. Nowadays, banks have realised that the success of a banking system without Information technology and it has expanded the role of the banking sector in the economy. All the banking transactions can now be processed quickly and easily with the help of Electronic banking. As can be observed from data given above, be it ATMs deployment, issuing of debit and credit card, transactions relating to NEFT, RTGS, Mobile banking (Values and Volumes) we can observe the growth in recent years. Our young generation has accepted the changes of the banking system for more as a convenience more than a challenge.

\section{Conflict of Interest: None.}

\section{Reference}

1. D Muraleedharan, Modern banking theory and practice, PHI learning private limited, Second Edition, 2014.

2. Jasdeep Kaur, Growth of E-Banking in India. International Journal of Research in Finance and Marketing (IJRFM). 2017:7(5):88-94.

3. Reeta and Manju Asht, E-banking in India: Current and Future prospects. IJABER. 2016;14(7):1.

4. Schlichter, Sarah (2007-02-05). "Using ATM's abroad - Travel - Travel Tips - msnbc.com". MSNBC. Retrieved 2011-02-11.

5. Daniel, E. (1999). Provision of electronic banking in the UK and the Republic of Ireland. International Journal of Bank Marketing, 1999;17(2):72-82.

6. Md. Abdul Hannan Mia, Mohammad Anisur Rahman and Md. Main Uddin, E-Banking: Evolution, Status and Prospects, The Cost and Management, 2007;35(1):36-48.

7. Dr.V. Antony Joe Raja, Global E-Banking Scenario And Challenges In Banking System, International Journal Of Management (IJM), 2012;3(1):205-213.

8. Agarwal, N., Agarwal, R., Sharma, P. and Sherry, A. M. (2003), 'E-banking for comprehensive E-Democracy: An Indian Discernment', Journal of Internet Banking and Commerce. 2003;8(1):03.

9. Mohan, K. (2006), 'Information Technology on Indian banking', SCMS Journal of Indian Management, July-Sept issue, pp. 18-24.

10. Raghavan, R.S. (2006), 'Perception of Indian banks in 2020', The Chartered Accountant. October issue, pp. 600-606.

11. Shukla, R. and Shukla, P. (2011). 'E-banking: Problems and Prospects', International Journal of Management \& Business Studies, 2011;1(1):23-25.

12. Uppal, R.K. and Chawla, R. 'E-Delivery channel-based banking services: An empirical study'. The Indian Journal of Management Research. 2009; VIII(7):7-33.

13. R.K. Uppal \& Rimpi Jatana, E-Banking in India - Challenges and Opportunities (2007), New Century Publications.

14. R. Krishnaveni, D. Divya Prabha. The Impact of Globalization on Banking Industry, South Asian Journal of Social Political Studies. 2005:6(1):75-80.

15. Zandi M, Singh V, Irving J (2013) “The Impact of Electronic Payment on Economic growth" https:/usa.visa.com/dam/vcom/download/corporate/media/moo dys-economy-white-paper.

16. Mukhopadhyay, B (2016), "understanding cashless payments in India, Financial innovation", 2.27 DOI 10.1186/s4854-0160047-4.

17. Mishra A. (2011). Internet Banking: Knowledge is prevention. Retrieved from http://www. ccaoi. in 11/links/fewnewsletter 15th\%20lan\%2()ll\%20Sivurity\%20Neu'sletter.pdf. 
18. Uppal R. K., "Customer Perception of E-Banking Services of Indian Banks: Some Survey Evidence", The ICFAI University Journal of Bank Management, 2008;VII(1):63-78.

19. Reserve Bank of India, Annual Report, various years. Report on trend and progress of banking in India.

a. (2012 to 2018), Report on trend and progress of banking in India.

b. (2012 to 2018), A Statistical table relating to banks in India.

c. https://www.rbi.org.in/SCRIPTs/PublicationReportDetail s.aspx? UrlPage $=\& \mathrm{ID}=243 \#$ ch 1

d. https://rbi.org.in/Scripts/FAQView.aspx?Id=60

e. https://m.rbi.org.in/Scripts/FAQView.aspx?Id=65

How to cite this article: Suhas. D, Ramesh H N. Ebanking and its growth in India - A synoptic view. J Manag Res Anal. 2018;5(4):376-383. 